\title{
Effect of dietary supplementation of marigold oleoresin on growth, survival and total muscle carotenoid of Koi carp, Cyprinus carpio $\mathrm{L}$.
}

\author{
Himanshu S. Swian*, S. Ratnamanjari Senapati ${ }^{1}$, S. J. Meshram², R. Mishra ${ }^{3}$ and \\ H. Shivananda Murthy ${ }^{2}$ \\ Central Inland Fisheries Research Institute, Barrackpore, Kolkata- 700120, INDIA \\ ${ }^{1}$ Central Institute of Fisheries Education, Mumbai- 400061, INDIA \\ ${ }^{2}$ College of Fisheries, Karnataka Veterinary Animal and Fisheries Sciences University, Mangalore-575002, INDIA \\ ${ }^{3}$ College of Fisheries, Odisha University of Agriculture and Technology, BBSR-760007, INDIA \\ *Corresponding author. E-mail: himanshufishco@gmail.com
}

Received: May 01, 2014 Revised received: August 23, 2014 Accepted: October 03, 2014

\begin{abstract}
The experiment was conducted to evaluate the effect of dietary supplementation of carotenoid (marigold oleoresin) on growth, survival and total body carotenoid of Koi carp (Cyprinus carpio). The experiment was carried out in 12 fiber aquarium tanks of size $12 " \times 6 " \times 6 "(201$ capacity). Each tank was stocked with 15 fishes of uniform size. The marigold oleoresin were as dietary supplement at levels $60,120,180,240,300 \mathrm{ppm} / \mathrm{kg}$ of the feed and designated as treatment $\mathrm{T}_{1}, \mathrm{~T}_{2}, \mathrm{~T}_{3}, \mathrm{~T}_{4}$ and $\mathrm{T}_{5}$ respectively and diet without marigold oleoresin supplementation served as a control $\left(T_{0}\right)$. The result of the experiment showed that there was significant difference found in absolute growth rate and specific growth rate of the fish $(P>0.05)$. However, 180ppm marigold oleoresin fed fishes showed higher mean weight gain of $3.98 \pm 0.22 \mathrm{~g}$ and lower feed conversion ratio (FCR) of $2.81 \pm 0.04$ than the other treatment groups. The body coloration and total carotenoid concentration of muscle tissue $(30.16 \pm 0.60 \mu \mathrm{g} / \mathrm{g})$ was significantly higher in fish fed with $180 \mathrm{ppm}$ marigold oleoresin diet. The study showed that incorporation of 180ppm of marigold oleoresin in diet was found better to enhance the growth and coloration in C. carpio.
\end{abstract}

Keywords: Carotenoid, Cyprinus carpio, Koi carp, Marigold oleoresin

\section{INTRODUCTION}

Ornamental fish sector has potential to contribute to the economic development in underdeveloped countries, especially tropics (Yanar et al., 2008). These are gaining importance because of their attractive coloration and aesthetic value. The pigments in ornamental fish are one of the most important quality criteria dictating the market value. Like other animals, fishes are unable to produce de novo (inside the body) synthesis of pigments. So the pigmentation of fish is due to ingested carotenoids (Goodwin, 1984). Among the important ornamental fishes, Koi carps are characterized by a wide diversity of colors and color patterns (Gomelsky et al., 2003). Koi value increases with intensity of skin color and this is because of absorption and deposition of carotenoids in body.

In nature, carotenoids have been implicated in diverse functions such as pigmentation, antioxidant activity, immunostimulation and reproduction, and they play a positive role in intermediary metabolism (McGraw and Ardia, 2003; Watanabe and Vasallo-Agius, 2003; Chatzifotis et al., 2005). In the natural environment, fish depends on aquatic vegetation to meet their carotenoid requirement. But culture of ornamental fish under high density in captive condition without supplementation of dietary carotenoids leads to faded coloration, disease and decrease the commercial value of the fish (Harpaz and Padowicz, 2007). Different sources of carotenoids pigments like pure carotenoids pigments, animal sources and plant sources are included in fish diet. Various synthetic pigments like $\beta$ carotene, castaxanthine, zeaxanthine and astaxanthine and also natural sources such as yeast, bacteria, algae, higher plants and in animal source, crustacean meal have been used as dietary supplements to enhance the pigmentation of fish and crustaceans (Shahidi et al., 1998; Kalinowski et al., 2005)

Among these natural compounds, many of the botanical additives have been used as cheapest sources of pigmentation in fish e.g. spirulina have been used as a source of carotenoid pigment for rainbow trout, fancy carp and yellow tail cichlid Pseudotropheus acei (Choubert, 1979; Boonyarapatin and Phrom kunthony, 1986). Marigold petal meal was used for the tiger barb and red swordtail (Boonyarapatin and Lovell, 1977; Ezhil et al., 2008). Ramamoorthy et al. (2010) have used natural carotenoid sources such as carrot (Daucus carota), marigold petal (Tagetes erecta), China rose petal (Hibiscus rosasinensis) and rose petal (Rosa 
chinensis) and found that they can enhance colour of marine ornamental fish Amphiprion ocellaris. Similarly $H$. rosasinensis, $R$. indica, Ixora coccinea and Crossandra infundibuliformiss have been utilized to enhance the growth and body colouration of an ornamental fish red sword tail, Xiphophorus hellerei (Baby Joseph et al., 2011). Marigold oleoresin, which is the hexane extract of the dehydrated marigold flowers (T. erecta) contain free fatty acids, waxes, sterols and the esterified lutein. The marigold contains various carotenoids, of which leutin is the principal component (Navarrete-Bolanos et al., 2005). Keeping this in view, the present study was conducted to know the effect of marigold oleoresin on growth, survival and total muscle carotenoid of Koi carp, C. carpio.

\section{MATERIALS AND METHODS}

Experimental design and experimental fish: The study was carried out in an indoor system of fiber glass aquaria tanks. Koi carps (C. carpio) were obtained from local commercial aquarium hatchery, kept under quarantine condition for three weeks and then acclimatized to the experimental condition for two weeks. During this period fishes were fed with basal diet (Control diet). Fishes of same color hue having initial weight of $2.60-2.68 \mathrm{~g}$ were selected for the experiment.

Experimental diet: A basal diet without adding carotenoid was used as control diet and five test diets namely $\mathrm{T}_{1}, \mathrm{~T}_{2}, \mathrm{~T}_{3}, \mathrm{~T}_{4}$ and $\mathrm{T}_{5}$ with inclusion level of marigold oleoresin 60, 120,180, 240 and $300 \mathrm{mg} / \mathrm{kg}$ were formulated using the square method of Hardy (1980). The experimental diets had $30 \%$ protein and the ingredients used in the formulation of different experimental diets were fishmeal, soybean meal, groundnut oil cake, wheat flour, rice bran, tapioca flour, vitamin and mineral premix. All the ingredients were analyzed for proximate composition prior to formulation of the test diets employing standard methods (AOAC, 2005). Moisture content was estimated by heating samples at $105{ }^{\circ} \mathrm{C}$ for $30 \mathrm{~min}$ and then cooling and weighing to a constant weight. Crude protein was analyzed using Kjeltec system (Tecater 1002 Distilling Unit), fat content by Soxtech system (Tecater 1043 Extraction Unit), fibre content by using Fibretech system (Tecater 1017 Hot Extractor). The ash content was determined by first drying the sample and then heating it in a Muffle furnace at $550 \pm 10^{\circ} \mathrm{C}$ for $6 \mathrm{~h}$. Marigold oleoresin was procured from M/S Avesthagen Ltd, Bangalore. A suspension of marigold oleoresin was made in soybean oil by heating it upto $55^{\circ} \mathrm{C}$ and was mixed with experimental diets on a slow mixer. Proximate composition of the ingredients and experimental diets are given in Table 1.

Fish feeding and sampling: Fish were fed at the rate of 5\% of their body weight till the end of the experiment. The feed was broadcasted over the surface of water twice daily at $10.00 \mathrm{~h}$ and $17.00 \mathrm{~h}$. After each sampling, the quantity of feed given was re-adjusted based on the increased weight of fish. Water in the experimental tanks was replaced with fresh and clean water every day. The fishes were sampled once in a fortnight and measured individually on electronic balance (Essae, India) to assess the growth. The stocked fishes were collected during each sampling and measured individually for growth parameters. After the experimental period of 60 days all the survived fishes were collected and their weight and survival data were recorded. The other growth parameters such as Specific growth rate (SGR) and Feed conversion ratio (FCR) were calculated by using the following formulae.

Specific growth rate $(\%)=[(\ln$ final weight $-\ln$ initial weight) / Rearing period (day) $] \times 100$

Feed conversion ratio $=$ Total dry feed offered $(\mathrm{g}) /$ Total wet weight gain $(\mathrm{g})$

Total carotenoid concentration (TCC) in the fish muscle tissue was analysed immediately after the completion of experiment following the pigment extraction method as described in Olson (1979). One gram body tissue of C. carpio was taken from headless and degutted fish and stored in a $10 \mathrm{ml}$ screw capped clear glass vials then added with $2.5 \mathrm{~g}$ of anhydrous sodium sulphate. The sample was gently meshed with a glass rod against the side of the vial and then $5 \mathrm{ml}$ of chloroform was added and left for overnight at $0^{\circ} \mathrm{C}$. when the chloroform formed a clear layer of 1-2 cm above the caked residue, the optical density was read at 380, 450, 470 and 500 $\mathrm{nm}$, in a spectrophotometer (Systronics, India) taking $0.3 \mathrm{ml}$ aliquots of chloroform diluted to $3 \mathrm{ml}$ with absolute ethanol. A blank prepared in a similar manner was used for comparison. The wave length at maximum absorption was recorded and used for the calculation.

Total carotenoid concentration $(\mu \mathrm{g} / \mathrm{g}$ wet wt.) = [Absorption at maximum wave length / (0.25 sample weight $(\mathrm{g})] \times 10$

(Where, $10=$ dilution factor; $0.25=$ Extinction coefficient)

Water quality analysis: The physico-chemical |parameters of water were analyzed for temperature (thermometer), $\mathrm{pH}$ (Hanna) and dissolved oxygen, carbon dioxide and ammonia in all the experimental tanks were estimated by standard methods (APHA, 1995).

Statistical analysis: The data is presented in the form of mean and standard error $( \pm$ S.E. $)$. The experimental results were tabulated and analyzed statistically by using One-way analysis of variance (ANOVA) and Duncan's multiple range tests was used for mean separation.

\section{RESULTS}

The changes in the growth during the 60 days of experiment are shown in the table 2 . The mean weight of Koi carp on the first day of stocking in the control $\left(\mathrm{T}_{0}\right)$ was $2.62 \mathrm{~g}$ and mean weight of carotenoid fed fishes group at 5 different concentrations such as 60 , $120,180,240$ and $300 \mathrm{mg} / \mathrm{kg}$ were $2.68 \mathrm{~g}, 2.60 \mathrm{~g}$, 
Himanshu S. Swian et al. / J. Appl. \& Nat. Sci. 6 (2): 430-435 (2014)

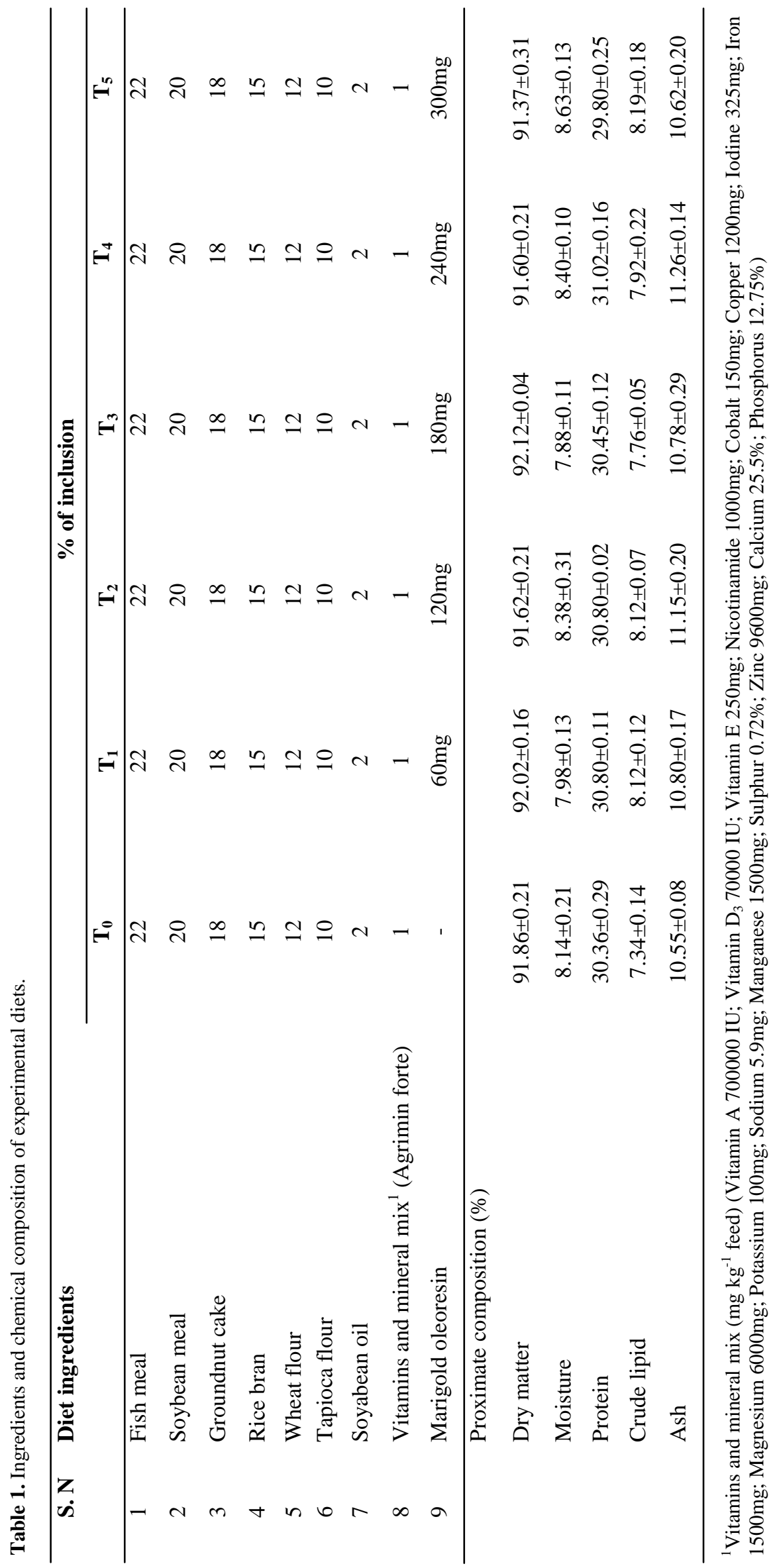


$2.60 \mathrm{~g}, 2.63 \mathrm{~g}$ and $2.62 \mathrm{~g}$ respectively. At the end of the experiment, the mean weight of the control fishes were found to be $6.08 \mathrm{~g}$ and the fishes fed with carotenoids, the mean weight observed to be $6.10 \mathrm{~g}, 6.06 \mathrm{~g}, 6.58 \mathrm{~g}$, $6.10 \mathrm{~g}$ and $5.98 \mathrm{~g}$ in $\mathrm{T}_{1}, \mathrm{~T}_{2}, \mathrm{~T}_{3}, \mathrm{~T}_{4}$ and $\mathrm{T}_{5}$ respectively. The food conversion ratio in different treatment varies from 3.18 in $\mathrm{T}_{5}$ to 2.81 in $\mathrm{T}_{3}$. The survival rate of fishes fed in different treatment with different level of marigold oleoresin and control diet ranged from 80.0 $\left(\mathrm{T}_{4}\right)$ to $90.33\left(\mathrm{~T}_{2}\right)$ is shown in table 2. Specific growth rate and Food conversion ratio was significantly varied among the treatments as shown in Table 2.

Total carotenoids concentration in body of $C$. carpio fed with experimental diets are presented in Table 3. $\mathrm{T}_{3}$ exibits highest total carotenoid $(30.16 \mu \mathrm{g} / \mathrm{g})$ content in body muscle followed by $\mathrm{T} 2(25.33 \mu \mathrm{g} / \mathrm{g}), \mathrm{T} 1(21.98$ $\mu \mathrm{g} / \mathrm{g})$, T4 (20.82 $\mu \mathrm{g} / \mathrm{g})$, T5 $(18.96 \mu \mathrm{g} / \mathrm{g})$ and $\mathrm{T}_{0}(4.10$ $\mu \mathrm{g} / \mathrm{g})$ at the end of the experiment. Significant ( $p>0.05$ ) increased trend of body carotenoids were observed in T3 group after fifteen days and which was continued throughout the experimental period. The physio-chemical parameters of water of the experimental tanks during the experimental period are presented in Table 4. The water temperature of the experiment varied between $27^{\circ} \mathrm{c}$ to $29.5^{\circ} \mathrm{c}$. The $\mathrm{pH}$ fluctuated from 7.2 to 7.9. The dissolved oxygen (DO) level showed variation from $5.5 \mathrm{mg}$ to $6.80 \mathrm{mg} / \mathrm{l}$. Total alkalinity varied from $70 \mathrm{ppm}$ to $90 \mathrm{ppm}$. The presence of free carbon dioxide and ammonia was in trace level throughout the experimental period.

\section{DISCUSSION}

Fishes use carotenoid as one of the most important group of natural pigment for pigmentation of the skin and flesh. As fish cannot synthesize these pigments de novo, they depend on a dietary supply of carotenoids to achieve their natural skin pigmentation, one of the quality criteria most in demand for the market value of ornamental high-value species such as goldfish (Lovell, 2000; Gouveia et al., 2003; Sinha and Asimi, 2007). Many commercial products extracted from marigold flower (Tagetes erecta) are being used throughout the world by poultry and nutraceutical industries. These products are rich in lutein and zeaxanthin, which play an important role as precursors of astaxanthin and enhance pigmentation of animals (Del Villar-Martínez et al., 2007).

In the present study survival rate of fish is not markedly different within the treatment but growth performance with respect to final mean weight and specific growth was significantly improved in fish fed with $180 \mathrm{mg} / \mathrm{kg}$ marigold oleoresin than the other lower and higher inclusion levels. Also the fish fed with $180 \mathrm{mg} / \mathrm{kg}$ marigold oleoresin supplemented diets showed lowest food conversion rate. These results are also in agreement with reports that link carotenoids to growth enhancement in Atlantic salmon fry (Salmo salar) (Christiansen et al., 1995), rainbow trout (Oncorhyncus mykiss) (De la 
Table 3. Total carotenoids concentration in body of Koi carp (C. carpio) fed with experimental diet ( $\mu \mathrm{g}$ of carotenoids / g of tissue).

\begin{tabular}{lcccccc}
\hline Treatments & Carotenoids $(\mathbf{m g} / \mathbf{k g})$ & \multicolumn{4}{c}{ Days } \\
\cline { 2 - 6 } & & Initial & 15days & 30days & 45days & 60days \\
\hline $\mathrm{T}_{0}$ & 0 & $4.3 \pm 0.0^{\mathrm{a}}$ & $4.45 \pm 0.04^{\mathrm{a}}$ & $4.21 \pm 0.22^{\mathrm{a}}$ & $4.13 \pm 0.24^{\mathrm{a}}$ & $4.10 \pm 0.28^{\mathrm{a}}$ \\
$\mathrm{T}_{1}$ & 60 & $4.3 \pm 0.0^{\mathrm{a}}$ & $5.26 \pm 0.11^{\mathrm{c}}$ & $7.26 \pm 0.21^{\mathrm{b}}$ & $12.54 \pm 0.37^{\mathrm{b}}$ & $21.98 \pm 0.26^{\mathrm{d}}$ \\
$\mathrm{T}_{2}$ & 120 & $4.3 \pm 0.0^{\mathrm{a}}$ & $6.06 \pm 0.13^{\mathrm{d}}$ & $9.10 \pm 0.30^{\mathrm{c}}$ & $16.18 \pm 0.40^{\mathrm{d}}$ & $25.33 \pm 0.8^{\mathrm{e}}$ \\
$\mathrm{T}_{3}$ & 180 & $4.3 \pm 0.0^{\mathrm{a}}$ & $6.52 \pm 0.20^{\mathrm{e}}$ & $10.95 \pm 0.41^{\mathrm{d}}$ & $18.0 \pm 0.21^{\mathrm{e}}$ & $30.16 \pm 0.60^{\mathrm{f}}$ \\
$\mathrm{T}_{4}$ & 240 & $4.3 \pm 0.0^{\mathrm{a}}$ & $5.10 \pm 0.09^{\mathrm{b}}$ & $8.86 \pm 0.18^{\mathrm{c}}$ & $13.20 \pm 0.24^{\mathrm{bc}}$ & $20.82 \pm 0.54^{\mathrm{c}}$ \\
$\mathrm{T}_{5}$ & 300 & $4.3 \pm 0.0^{\mathrm{a}}$ & $5.12 \pm 0.16^{\mathrm{b}}$ & $9.08 \pm 0.20^{\mathrm{c}}$ & $14.45 \pm 0.34^{\mathrm{c}}$ & $18.96 \pm 0.39^{\mathrm{b}}$ \\
\hline
\end{tabular}

Different superscript indicates significant difference $(\mathrm{P}<0.05)$

Table 4. Physico-chemical parameters of water during the experimental period.

\begin{tabular}{lc}
\hline Parameters & Values \\
\hline Temperature $\left({ }^{\circ} \mathrm{C}\right)$ & $27.0^{\circ} \mathrm{C}-29.5^{\circ} \mathrm{C}$ \\
DO $\left(\mathrm{mgl}^{-1}\right)$ & $5.5-6.80$ \\
pH & $7.2-7.9$ \\
Free carbon dioxide $\left(\mathrm{mgl}^{-1}\right)$ & $1.40-2.80$ \\
Total alkalinity $\left(\mathrm{mgl}^{-1}\right)$ & $70-99$ \\
Ammonia- nitrogen $\left(\mu \mathrm{gl}^{-1}\right)$ & $0.02-0.32$ \\
\hline
\end{tabular}

Mora et al., 2006) and goldfish (Carassius auratus) (Sinha and Asimi, 2007) Further, observation was made by Ahilan et al. (2008) in gold fish fed with coriander incorporation feed at 3 percent level showed better biological performance like weight gain and specific growth rate when compared to other coriander in corporate diet and control. According to Tveranger (1986) and Sommer et al. (1992), the addition of carotenoids rich microalgae and krill meal enhanced the growth of trout.

The carotenoids deposition was significantly higher in fish body fed with carotenoids supplemented diet (with $180 \mathrm{mg} / \mathrm{kg}$ of Marigold oleoresin) diet than unsupplemented control and other inclusion level of carotenoid in diet. It is observed that $250 \mathrm{mg}$ of astain supplementation per $\mathrm{kg}$ of diet showed highest carotenoids deposition in Koi carp (Liang et al., 2012) and at a low concentration $(60 \mathrm{mg} / \mathrm{kg})$ a saturation point in the accumulation of carotenoids was reached in adult Dwarf cichilid (Harpaz, 2007). Similar results were obtained for goldfish by feeding different natural carotenoid sources, such as Spirulina (Kiriratnikom et al., 2005), microalgal biomass (Gouveia and Rema, 2005), red yeast (Xanthophyllomyces dendrorthous) (Xu et al., 2006) and alfalfa (Medicago sativa) (Yanar et al., 2008). The results obtained in the current study concludes that the pigmentation in skin of Koi carp increased with a level up to $180 \mathrm{ppm}$ of carotenoids $/ \mathrm{kg}$ of feed from marigold oleoresin, over that level there was no additional carotenoid accumulation in fish body. Current findings are supported by Yanar et al. (2008) mentioned that carotenoid uptake or transportation to the tissue was saturated due to carotenoid inclusion level $(200 \mathrm{mg})$ in goldfish. The effectiveness of a carotenoid source for pigment deposition is species specific (Ha et al., 1993).

\section{Conclusion}

The present study concluded that marigold oleoresin (180 mg/kg of feed) as a carotenoid source was effective on growth and skin pigmentation of Koi carp as it led to nearly maximum carotenoids accumulation in the boy of goldfish.

\section{REFERENCES}

Ahilan, B., Jegan, K., Felix, N. and Ravaneswaran, K. (2008). Influence of botanical additives on the growth and colouration of adult goldfish, carassius auratus (linnaeus). Tamil Nadu J. Veterinary \& Animal Sciences, 4 (4): 129-134.

AOAC. (2005). Official methods of analysis of AOAC, 18th edition, In: Horwitz, W. (Ed.), AOAC, Washington, .D.C., 1094.

APHA.(1995). Standard methods for the Examination of water and Wastewater. $18^{\text {th }}$. Edn., American Public Health Association, Washington DC. Aquaculture 17: 63-92.

Baby Joseph, S., Sujath, J., Jemima, Shalin and Palavesam, A. (2011). Influence of four ornamental flowers on the growth and colouration of orange sword tail Chicilidae fish (Xiphophorus hellerei, Heckel, 1940). Int J Biol Med. Res., 2(3): 621-626.

Boonyarapatin, M. and Lovell, R.T. (1977). Diet preparation for aquarium fish. Aquac., 12: 53-62.

Boonyarapatin, M. and Phrom kunthony, W. (1986). Effects of carotenoid pigments from different sources on colour changes of fancy carp, Cyprinus carpio. Linn. Jour. Sci. Technol., 8(1): 11-20.

Chatzifotis, S., Pavlidis, M., Jimeno, C.D., Vardanis, G., Sterioti, A. and Divanach, P. (2005). The effect of different carotenoid sources on skin coloration of cultured red porgy (Pagrus pagrus). Aquaculture Research, 36:1517-1525.

Choubert, G. (1979). Tentative utilization of spirulina algae as a source of carotenoid pigmentsa for rainbow trout. Aquac., 18: 135-143.

Christiansen, R., Lie, O. and Torrissen, O.J. (1995). Growth and survival of Atlantic salmon, Salmo salar L., fed different dietary levels of astaxanthin. First-feeding fry. Aquaculture Nutrition. 1: 189-198.

Del Villar-Martinez, M., Serrato-Cruz, M.A., SolanoNavarro, A., Arenas-Ocampo, M.L., Quintero-Gutiérrez, A.G., Sánchez-Millán, J.L., Evangelista-Lozano, S., Jiménez 
Aparicio, A., García-Jiménez, F.A. and Vanegas-Espinoza, P.E. (2007). Carotenoides en Tagetes erecta $\mathrm{L}$. la modificación genética como alternativa. Rev. Fitotec. Mex., 30 (2):109-118.

De la Mora, G.I., Arredondo-Figueroa, J.L., Ponce-Palafox, J.T. , Barriga-Sosa, I.A. and Vernon-Carter, J.E. (2006). Comparison of red chilli (Capsium annuиm) oleoresin and astaxanthin on rainbow trout (Oncorhynchus mykiss) fillet pigmentation. Aquaculture. 258: 487-495.

Ezhil, J., Jeyanthi, C. and Narayanan, M. (2008). Marigold as a carotenoid source on pigmentation and growth of red swordtail, Xiphophorus helleri. Turkish Journal of Fisheries and Aquatic Sciences, 8: 99-102.

Goodwin, T.W. (1984). The Biochemistry of carotenoids. Volume II. Animals. Chapman and Hall, New York,

Gomelsky B., Cherfas, N., Hulata, G. and Dasgupta, S. (2003). Inheritance of the white-red (kohaku) color complex in ornamental (koi) carp (Cyprinus carpio L.). Isr. J. Aquacult. - Bamidgeh, 55(3):147-153.

Gouveia, L. and Rema, P. (2005). Effect of microalgal biomass concentration and temperature on ornamental fish (Cyprinus carpio) skin pigmentation. Aquaculture Nutrition, 11: 19-23.

Gouveia, L., Rema, P., Pereira, O. and Empis, J. (2003). Colouring ornamental fish (Cyprinus carpio and Carassius auratus) with microalgal biomass. Aquaculture Nutrition, 9: 123-129.

Ha, B. S., Kang, D. S., Kim, J.H., Choi O. S. and Ryu, H. Y. (1993). Metabolism of dietary carotenoids and effects to improve the body color of cultured flounder and red sea bream. Bulletin of Korean Fishery Society, 26: 91- 101.

Hardy, R. (1980). Fish feed formulation, In: ADCP (Eds.), Fish feed Technology, Agriculture development coordination programme. FAO/ADCP/Rep., 80(1-1): 233-239.

Harpaz S. and Padowicz, D. (2007). Color enhancement in the ornamental dwarf cichlid Microgeophagus ramirezi by addition of pant carotenoids to the fish diet. The Israeli Journal of Aquaculture, 59 (4), 195-200.

Kalinowski, C.T., Robaina, L.E., Fernadez-Palacios, H., Schuchardt, D. and Izquierdo, M.S. (2005). Effect of different carotenoid sources and their dietary levels on red porgy (Pagrus pagrus) growth and skin colour. Aquaculture, 244: 223-231.

Kiriratnikom, S., Zaau, R. and Suwanpugdee, A. (2005). Effects of various levels of Spirulina on growth performance and pigmentation in goldfish (Carassius auratus). Songklanakarin Journal of Science and Technology, 27: 133-139.

Liang, Y., Dong-qing Bai, Guang Yang, Dong Wei, MeiGuo, Shan-shan Yan, Xuan Wu, Bo Ning (2012).
Effect of astacin on growth and color formation of Juvenile Red-White ornamental carp (Cyprinus carpio var. koi L) The Israeli Journal of Aquaculture, 64.748: 1-6.

Lovell, R.T. (2000). Nutrition of ornamental fish. In: J. Bonagura (Ed.). Kirk's Current Veterinary Therapy XIISmall Practice, W.B. Saunders, Philadelphia, pp. 1191-1196.

McGraw, K.J. and Ardia, D.R. (2003). Carotenoids, immunocompetence, and the information content of sexual colors: and experimental test. American Nature, 162: 704-712.

Navarrete-Bolanos, J.L., Rangel-Cruz, C.L., Jimenez-Islas, H., Botello-Alvarez, E. and Rico-Martinez, R. (2005). Pre-treatment effects on the extraction efficiency of xanthopylls from marigold flower (Tagetes erecta) using hexane. Food Research International, 38: 159-165

Olson, A. (1979). A simple dual assay for vitamin A and carotenoids in human and liver. Nutrition report international, 19: 807-813.

Ramamoorthy, K., Bhuvaneswari, S., Sankar, G. and Sakkaravarthi, K. (2010). Proximate composition and carotenoid content of natural carotenoid sources and its colour enhancement on marine ornamental fish Amphiprion ocellaris (Cuveir, 1880). World Journal of Fish and Marine Sciences, 2 (6): 545-550.

Shahidi, F., Metusalach and Brown, J.A. (1998). Carotenoid pigments in seafoods and aquaculture. Critical Reviews in Food Science and Nutrition, 38: 1-67.

Sinha, A. and Asimi, O. A. (2007). China rose (Hibiscus rosasinensis) petals: a potent natural carotenoid source for goldfish (Carassius auratus L.). Aquaculture Research, 38: 1123-1128.

Sommer, T. R., Souza, F. M. L. D. and Morrisssy, N. M. (1992). Pigmentation of adult rainbow trout Oncorhynchus mykiss, using the green alga Haematococcus Pluvialis. Aquaculture, 106: 63-74.

Tveranger, B. (1986). Effect of pigment content in broodstock diet subsequent fertilization rate,survival and growth rate of rainbow trout (Salmo gairdneri) offspring. Aquaculture, 53: 85-93.

Watanabe, T. and Carotenoid Vasallo-Agius, R. (2003). Broodstock nutrition research on marine finfish in Japan. Aquaculture, 227: 35-61.

Xu, X., Jin, Z., Wang, H., Chen, X., Wang, C. and Yu, S. (2006). Effect of astaxanthin from Xanthophyllomyces dendrorhus on pigmentation of goldfish, Carassius auratus. Journal of the World Aquaculture Society, 37: 282-288.

Yanar, M., Erçen, Z., Hunt, A.O. and Buyükçapar, H.M. (2008). The use of alfafa, Mendicago sativa as natural carotenoid source in diets of goldfish, Carassius auratus. Aquaculture, 284: 196-200. 